\title{
Sociedade do Cansaço
}

\section{Márcia Fernanda de Méllo Mendes}

Educadora física, mestre em saúde coletiva (UFRGS), professora do Instituto Federal do Rio Grande do Sul (IFRS) e doutoranda em Antropologia e Comunicação na Universitat Rovira i Virgili (URV) em cooperação com o Programa de Pós-Graduação em Psicologia da UFPA.

E-mail:marciafernandammendes@gmail.com

\section{Deborah Bekele}

Antropóloga, doutoranda em Antropologia e Comunicaçao na Universitat Rovira i Virgili (URV).

E-mail: deborah.bekele@estudiants.urv.cat
O Livro Sociedade do Cansaço ${ }^{1}$ foi escrito por um filósofo de origem coreana, que fixou-se na Alemanha. É composto por sete capítulos e dois anexos, que aprofundam temas como passagem da sociedade de controle para a sociedade do desempenho e as consequências na vida cotidiana, marcada por patologias vinculadas ao excesso e a positividade. A base epistemológica das reflexões é de autores como Platão, Aristóteles, Arendt, Agamben, Nietzsche, Kant, Freud, entre outros, para dialogar, contrapor e aprofundar seus conceitos.

No primeiro capítulo, "A Violência Neuronal", o autor afirma que estamos vivendo a época das doenças neuronais, marcada por patologias como depressão, transtorno de déficit de atenção e hiperatividade, transtorno de personalidade limítrofe, Síndrome de Burnout, doenças estas provocadas pelo excesso. As épocas anteriores são descritas como a bacteriológica e a viral, marcadas pela negatividade de afastar tudo que é estranho, uma concepção que ultrapassa o campo 
imunológico chegando ao âmbito social. A reação imunológica caracteriza-se por uma reação à alteridade, que tem como profilaxia a vacina, caracteriza-se como a negação da negação que ocorre sem perigo à vida, chegando a ser permitido o uso de uma forma de autoviolência para proteger-se de uma violência ainda maior. No entanto, nos dias atuais, nas patologias neuronais, entram em cena a diferença que não provoca nenhuma reação e já não adoece, ela se naturaliza no consumo, dando lugar ao exótico. $\mathrm{O}$ imigrante, por exemplo, não é mais visto como um outro que oferece risco ou um estrangeiro representando um perigo real (época bacteriológica e viral), ele é visto, na época neuronal, como um peso a ser carregado. A violência oriunda da positividade, superprodução, superdesempenho e supercomunicação provoca o esgotamento, a exaustão e o sufocamento reflexos de uma sociedade permissiva e pacificada onde este tipo de violência é invisível e inacessível a uma percepção direta.

Nesta sociedade, o sujeito passa a ser empresário de si, absorvido na busca do desempenho e produção. Han parte dos conceitos de sociedade disciplinar e sociedade do controle (conceitos de Foucault) para descrever a transição para a sociedade do desempenho no segundo capítulo do seu livro. Uma afirmação característica deste tempo é yes, we can (sim, nós podemos) que demonstra a positividade do poder em oposição à negatividade do dever. Não é mais necessária uma coação externa, o homem depressivo é o animal trabalhador que não pode mais poder, é, ao mesmo tempo, a vítima e seu próprio algoz em um contexto de uma liberdade paradoxal. 0 conceito de animal trabalhador é aprofundado no capítulo 4, chamado Vida Activa. O modelo de empresário de si gera uma falsa sensação se liberdade. No entanto, o excesso de positividade e o não poder dizer não desencadeiam processos de coerção e violência, em geral, imperceptíveis. Uma técnica eficaz para a produção e desempenho é a multitarefa, o autor explica no capítulo 3 que não é algo inovador, mas sim um retrocesso que aproximando o homem ao animal que por extinto de sobrevivência divide sua atenção em diferentes atividades. A contemplação e a atenção profunda tem sido deslocadas para a hiperatenção, com baixa tolerância ao tédio que é fundamental para o processo criativo.

O autor segue seu livro com o capítulo "Vida Ativa", no qual discute o conceito de Hannah Arendt. Para a autora, o agir tem uma ênfase heroica vinculada ao nascimento e configura-se como uma forma de ativar novos processos. No 
entanto, a modernidade tem gerado uma passividade mortal, sendo que o agir e o produzir relacionam se diretamente ao trabalho, reduzindo o homem a um animal trabalhador. Na pós-modernidade, a transitoriedade é algo real, que não se relaciona somente a vida humana, mas com mundo da forma que é hoje. Neste cenário, o homem animal trabalhador vive novas coerções, não é mais passivo e todas as atividades comuns da vida cotidiana Ihe geram uma agitação nervosa produzindo sujeitos hiperativos e hiperneuróticos, carentes de ser. Como alternativa, o autor diz que mesmo sem perceber, Hannah Arendt menciona a linguagem da vida contemplativa, e afirma que a perda da capacidade de contemplar, característica da sociedade ativa moderna, é corresponsável pela sua histeria e nervosismo.

No capítulo 5, o autor problematiza a necessidade de aprender a ver, permitindo-se um olhar demorado e lento sem uma reação imediata, enfim a capacidade de contemplar. A reação imediata, característica do nosso tempo, pode ser vista como um sintoma do esgotamento, uma hiperatividade que paradoxalmente se converte em hiperpassividade e gera a ilusão de uma liberdade, mas que na verdade gera mais coerções. O homem padece em um mundo pobre de interrupções, necessitando da negatividade do corte, do parar interiormente para perceber o todo que não está em uma atividade. Já a positividade, produz pensamento disperso, sem reflexão e conectado a diversos objetos. Esta crescente positivação da sociedade não dá margens a reflexão e a percepção da diferença, provocando um estado de normalidade totalitário que absorve todo e qualquer estado de exceção.

No capítulo seguinte, o autor utiliza o texto de Melvilles sobre Bartleby para descrever as características de uma sociedade disciplinar, afirma que na sociedade disciplinar não há sintomas de depressão, já que a sensação de insuficiência e angústia frente ao fracasso não fazem parte dos sentimentos possíveis no contexto. O imperativo pós-moderno, do continuo produzir exige que se abandone 0 próprio eu. A história Bartleby, descreve o esgotamento vivido na Wall Street, onde só a negatividade da recusa usada pelo personagem, Ihe dá liberdade.

Chul Han, segue seu livro como capítulo "Sociedade do Cansaço" abordando como a sociedade do desempenho tem-se utilizado de uma forma de doping para o melhoramento cognitivo, a vitalidade como um fenômeno 
complexo perde valor reduzindo-a a função vital. Assim temos uma sociedade do excesso, do desempenho, uma sociedade ativa que gera o esgotamento e um cansaço solitário pela positividade. Também é uma forma de violência que acaba com a comunidade, tornando possível uma sociedade que não precisa de pertença. Ele finaliza este capítulo contrapondo a sociedade ativa à "sociedade petencostal", composta por cansados sem sentido específico, afirma que se o futuro fosse este, teríamos a sociedade do cansaço. O livro segue com o anexo "Sociedade do Esgotamento" onde o autor faz uma análise dos conceitos de Freud e das mudanças da sociedade disciplinar para sociedade do desempenho, apontando uma reestruturação da psique. $\mathrm{O}$ aparato psíquico proposto por Freud é dominado pelo medo e angustia perante a transgressão, no entanto, no sujeito do desempenho vê-se o sujeito da afirmação. Este sujeito não se submete mais a um trabalho compulsório e nem está à espera da gratificação que o sofrimento poderia Ihe causar. Ele busca prazer e passa a ser um empreendedor de si mesmo, um estado de liberdade que que força a produzir mais, sem jamais alcançar um ponto de gratificação. Uma nova forma de coação, dissimulada, impede que os sentimentos negativos sejam percebido, e assim, o conflito deste modo de vida e funcionamento não emerge.
O autor constrói uma nova forma de olhar o adoecimento psíquico como depressão e burnout, descrevendo como consequências da incapacidade de dizer não, de poder não fazer tudo. Uma forma de autodestruição que ganha concretude no colapso nervoso ou em síndromes como burnout, nesta forma de viver, o homem equipara-se a mortos-vivos, que estão vivos demais para morrer e mortos demais para viver.

No segundo anexo, intitulado "Tempo de celebração - a festa numa época sem celebração" o autor encerra seu livro dando pistas de formas de resistência a sociedade do desempenho, para isto oferece ao leitor o conceito de festa em contraponto ao evento. $\mathrm{O}$ tempo da festa é um tempo que não passa, é um espaço onde nos demoramos, situação difícil de identificar hoje em dia, vivemos a temporalidade do evento ou do espetáculo, a vida é marcada pela eventualidade. A palavra festa tem origens religiosas, sendo um momento onde nos tornamos divinos, Han se refere ao livro do Platão, Nomoi (As leis) que fala que o homem e a mulher foram feitos por Deus para brincar e jogar, todavia as manifestações como fazer oferendas, dançar e cantar serviam para desperta a graça dos deuses. No entanto, hoje, somos escravos do trabalho, do desempenho e da produção nos 
afastando da divindade. Para a crise atual, o autor sugere que devemos criar uma forma de vida que recupere a estagnação, para isto é importante perceber a diferença entre parar e pausar. Na pausa ou desaceleração o objetivo é a recuperação para voltar a trabalhar, continuar funcionando em oposição temos o estagnar caracterizado por um tempo pleno de elevada intensidade vital.

Han encerra seu livro citando as três formas de vida livre, segundo Aristóteles: a que goza das coisas belas, a que produz belos atos na polis e a vida contemplativa, sendo assim, são livres os poetas, os políticos e os filósofos, no entanto hoje a política está deturpada, os políticos se submeteram ao sistema que resulta em uma ditadura do capital. O hipercapitalismo transforma todas as relações em comerciais, a dignidade humana é substituída pelo valor de mercado e a sociedade vai se transformando em um grande e única loja comercial, repleta de objetos e mercadorias com vida útil e validade cada vez menores. Muito semelhante ao manicômio, onde temos tudo, mas nos falta o essencial, o mundo. $\mathrm{O}$ autor afirma que está na hora de transformar esta loja que se transformou o mundo em uma moradia, uma casa de festas, onde valha a pena viver.

\section{Referências}

${ }^{1}$ HAN, Byung-Chul. Sociedade do cansaço. 2. Ed. ampl. Petrópolis: Vozes; 2017.

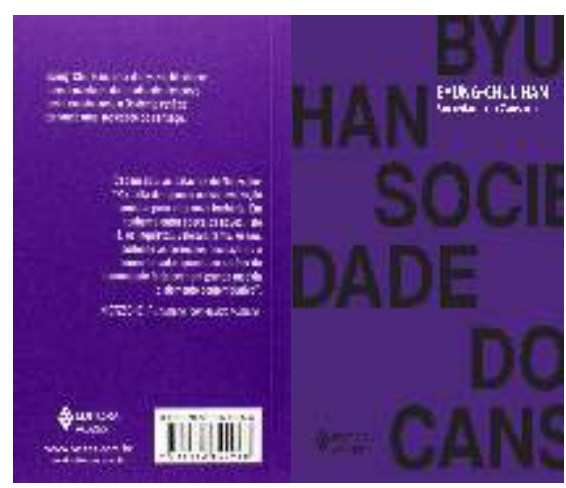

